\title{
Salinity modulates the energy balance and reproductive success of co-occurring copepods Acartia tonsa and $A$. clausi in different ways
}

\author{
Danilo Calliari ${ }^{1,2, *}$, Christian Marc Andersen ${ }^{3}$, ${\text { Peter } \text { Thor }^{4} \text {, Elena Gorokhova }}^{3}$, \\ Peter Tiselius ${ }^{4}$ \\ ${ }^{1}$ The Royal Swedish Academy of Science, Kristineberg Marine Research Station, 45034 Fiskebäckskil, Sweden \\ ${ }^{2}$ Sección Oceanología, Facultad de Ciencias, Universidad de la República, Iguá 4225 CP 11400, Montevideo, Uruguay \\ ${ }^{3}$ Department of Systems Ecology, Stockholm University, 10691 Stockholm, Sweden \\ ${ }^{4}$ Department of Marine Ecology, Göteborg University, Kristineberg Marine Research Station, 45034 Fiskebäckskil, Sweden
}

\begin{abstract}
We assessed metabolic balance, RNA content, and egg hatching success (EHS) in Acartia tonsa and $A$. clausi over a wide salinity range ( 2 to 33 and 16 to 33, respectively). For $A$. tonsa, the energy partitioning between ingestion, production and respiration was relatively constant with small differences in gross growth efficiency (GGE) and cost of growth (CG). In contrast, A. clausi exhibited significantly reduced ingestion and GGE, and highly elevated CG at salinities $\leq 20$. In both species, RNA levels mirrored egg production. EHS was generally high in both species, but decreased by $80 \%$ for A. clausi at 16 . These results contribute to the understanding of distribution patterns of both species along salinity gradients. The observed responses would allow the dominance of $A$. tonsa at low salinities, although its higher energetic requirement and feeding activity subject it to stronger predation pressure than competing A. clausi.
\end{abstract}

KEY WORDS: Acartia clausi · Acartia tonsa - Salinity · Metabolic balance · Fitness $\cdot$ RNA content Distribution

Resale or republication not permitted without written consent of the publisher

\section{INTRODUCTION}

Salinity is a major environmental variable influencing the distribution of marine organisms. Diluted waters of estuaries and coastal areas restrict the survival of stenohaline zooplankton, and the pronounced salinity gradients often determine the spatial succession of copepods (Jeffries 1962, Cervetto et al. 1999). Moreover, exposure to abrupt changes in salinity caused by estuarine circulation can be fatal for some species (Soetaert \& Herman 1994). Coastal communities are thus less diverse than their oceanic counterparts, and copepod plankton is dominated by only a few genera.

Copepods are the most abundant metazoans on Earth and constitute a key link in the transfer of organic mat- ter to larger consumers in marine ecosystems (Mauchline 1998). However, their physiological and ecological responses to salinity changes are not fully understood despite the acknowledged importance of this environmental variable. Relatively few studies have focused on osmoregulation (Lance 1965, Brand \& Bayly 1971, Farmer 1980) and physiological responses, e.g. feeding (Lance 1964), production (Gaudy et al. 2000, CastroLongoria 2003), or respiration (Lance 1965, Gaudy et al. 2000). Several euryhaline copepods are osmoregulators, as are many other crustaceans (Brand \& Bayly 1971, Farmer 1980, Roddie et al. 1984, Mauchline 1998). Active ionic regulation represents a steady state maintained by expenditure of metabolic energy (Schmidt-Nielsen 1991). Thus, considering energy balance, it can be expected that over the salinity range 
where minimum energy is required for osmoregulation, a maximum fraction of the acquired energy will be channeled to production (Gaudy et al. 2000).

Copepod bioenergetics theory predicts that feeding, growth and respiration are positively correlated; increased respiration normally follows shortly after feeding (Thor 2003), a general phenomenon known as specific dynamic action (SDA), which reflects the metabolic cost of food processing and protein synthesis (Kiørboe et al. 1985). Concurrent analyses of the basic constituents of metabolism, i.e. feeding, growth, respiration and egestion under controlled experimental conditions can give insights into physiological performance and energy allocation under different salinities. Also, biochemical indicators, and in particular RNAbased indices (i.e. RNA concentration, RNA:DNA and RNA:protein ratios), are useful for determining physiological condition, as well as quantifying stress response (Dahlhoff 2004), including osmotic stress in crustaceans (Wang et al. 2004). Thus, using RNA concentration as an index of metabolic activity, it might be possible to assay suborganismal (i.e. cellular or molecular level) effects of salinity on physiological performance.

Acartia tonsa Dana and A. clausi Giesbrecht are common euryhaline copepods in temperate and subtropical coastal areas worldwide, and they have been used as model organisms in a wide range of studies (for a review see Mauchline 1998). The objective of this paper is to comparatively assess salinity effects on metabolic energy partitioning and egg hatching success (EHS) of these 2 species, as these are the key parameters for individual fitness and population dynamics. In addition, we attempted to use individual RNA levels of experimental animals to assay their physiological condition and to relate these to other measured variables.

\section{MATERIALS AND METHODS}

We measured rates of filtering, respiration, egestion and egg production, RNA content in adult females, and EHS at 5 different salinities: 32.5, 20.0, 10.0, 5.0 and 2.0 for Acartia tonsa, and 32.5, 28.0, 24.0, 20.0 and 16.0 for A. clausi. For simplicity, 32.5 is referred to as 33 hereafter. Experimental animals were obtained from laboratory cultures originating from Øresund (Denmark, A. tonsa) and Ria de Aveiro populations (Portugal, A. clausi), both kept for several generations at a salinity of ca. 33 in the laboratory (below-pycnocline water, BPW, from the Gullmarsfjord, Sweden). The temperature during experiments was $18^{\circ} \mathrm{C}\left( \pm 0.5^{\circ} \mathrm{C}\right)$. This temperature fits adequately within the natural range experienced by both A. tonsa and A. clausi (Gonzalez 1974,
Mauchline 1998), and is the temperature at which the cultures were maintained.

Water dilutions were prepared by mixing appropriate volumes of $0.45 \mu \mathrm{m}$-filtered BPW and distilled water, and final salinity was checked using a WTW LF196 salinometer. Salinity values thus correspond to the practical salinity scale and are reported without units. To minimize stress, experimental animals were gradually acclimated to experimental conditions in dilution steps of 3 to 6 at a time every $12 \mathrm{~h}$. The final acclimation to experimental salinity and food conditions lasted for $24 \mathrm{~h}$. Preliminary experiments revealed that Acartia clausi did not tolerate salinities below 15 even under this acclimation regime; therefore, the salinity range for this species was restricted to between 33 and 16.

During the experiments, copepods were fed the diatom Thalassiosira weissflogii Fryxell \& Hasle (strain GUMACC-91, Göteborg University Marine Algal Culture Centre) taken from batch cultures during exponential growth and supplied at $100 \mathrm{\mu g} \mathrm{Cl}^{-1}$. This food level is below saturation for both Acartia tonsa (Berggreen et al. 1988) and A. clausi (Dutz 1998). Algal carbon content was estimated from cell volume according to Mullin et al. (1966), and volume estimates derived from Equivalent Spherical Diameter (ESD) measurements using an electronic particle analyzer (Elzone 5380, 95- $\mu \mathrm{m}$ orifice tube). Food-limiting conditions were expected to allow a better detection of salinity effects on copepod physiology. Ad libitum feeding may facilitate compensating for a deficiency caused by the test variable (i.e. salinity), and so animals with excess food may still do quite well under non-optimal salinities. Thus, excess food may mask the effect of salinity on physiological adaptations and energy budget (Jonasdottir et al. 1998).

Feeding, egg production and egestion experiments. For each salinity treatment, 10 to 15 recently molted adult females were transferred to each of 4 replicate $620 \mathrm{ml}$ bottles filled with the experimental suspension. Four control bottles contained the same suspension but without copepods. All bottles were sealed to prevent air bubbles, and placed on a rotating wheel $(0.2 \mathrm{rpm})$ under a natural light:dark cycle. After $24 \mathrm{~h}$, the contents of the bottles were sieved onto a $50 \mu \mathrm{m}$ mesh, the number of surviving copepods recorded, and all the eggs and fecal pellets counted (dissection microscope at $40 \times$ ) to estimate egg production rates (EPR, eggs ind. ${ }^{-1} \mathrm{~d}^{-1}$ ) and pellet production rates ( $P P R_{i}$ pellets ind. ${ }^{-1} \mathrm{~d}^{-1}$ ). Also, 50 eggs (diameter) and ca. 50 pellets (length and width) were measured for each species and salinity (inverted microscope at $400 x_{i}$ for Acartia clausi, pellets were measured at salinities 16, 24 and 28). Feeding was estimated as filtering rate $\left(F_{i} m l\right.$ ind..$^{-1}$ $\mathrm{d}^{-1}$ ) according to Frost (1972) by counting cell numbers 
with the Elzone at the end of the incubations in experimental and control bottles; ingestion was calculated as the product of $\mathrm{F}$ times food concentration averaged during the incubation period. Food levels by the end of the incubations decreased by 16 to $36 \%$ in $A$. tonsa and 4 to $22 \%$ in A. clausi experiments.

EPR were converted to carbon units ( $\mu \mathrm{gC}$ ind.$^{-1} \mathrm{~d}^{-1}$ )

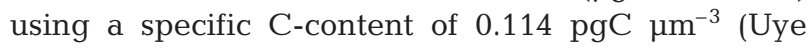
1981). Egg diameter used for production estimates was $82 \pm 1.7$ (SD) $\mu \mathrm{m}$ for Acartia tonsa (corresponding to a salinity of 33 ) and $77 \pm 2.3 \mu \mathrm{m}$ for $A$. clausi (corresponding to salinities between 20 and 33), equi-

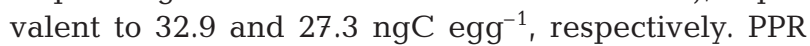
were converted to carbon units assuming an ellipsoid shape and a specific C-content following Urban-Rich et al. (1998).

To estimate weight-specific rates $\left(\mu \mathrm{gC} \mu \mathrm{gC}^{-1} \mathrm{~d}^{-1}\right)$, females were measured after the experiments (prosome length; dissection microscope at 40×), and individual carbon content was calculated according to Uye (1982, for Acartia clausi) and Berggreen et al. (1988, for A. tonsa). The females were then transferred individually into $0.5 \mathrm{ml}$ Eppendorf tubes containing $20 \mu \mathrm{l}$ of RNAlater (Ambion) and stored at 4 to $6^{\circ} \mathrm{C}$ for RNA determination. Cannibalized eggs were recognized from their crumpled eggshells and considered for calculation of EPR.

Hatching experiments. Eggs were transferred to tissue-culturing wells filled with filtered water of the corresponding salinity. After $24 \mathrm{~h}$, the number of nauplii was recorded and EHS calculated as the number of nauplii divided by the total number of eggs produced. Realized Fecundity (RF) was calculated as nauplii produced per female per day. Cannibalized eggs were not considered for estimation of EHS.

RNA measurements. A microplate fluorometric high-range assay with RiboGreen was performed to quantify RNA in individual copepods (expressed as percent of carbon mass) after extraction with N-laurylsarcosine followed by RNase digestion as described by Gorokhova \& Kyle (2002). The following working reagents were used: RiboGreen ${ }^{\mathrm{TM}}$ RNA Quantitation Kit (Molecular Probes, cat. \# R11490); RNase, DNasefree (Q-biogene, cat. \# RNAS0500), working solution $5 \mu \mathrm{g} \mathrm{ml} \mathrm{m}^{-1}$; N-lauroysarcosine (sarcosyl, Sigma, cat. \# L-5125); TE buffer (Q-biogene, cat. \# TE1X0001). Fluorescence measurements were performed using fluorometer FLUOstar Optima (BMG Labtechnologies, microplate reader, filters: $485 \mathrm{~nm}$ for excitation and $520 \mathrm{~nm}$ for emission) and black solid flat-bottom microplates (COMBO; Labsystems, cat. \# 9502067). The plate was scanned with a $0.2 \mathrm{~s}$ well measurement time and 10 measurements were made per well.

Respiration experiments. Respiration was measured as oxygen consumption using the flow-through tech- nique; a detailed description of the experimental set-up is found in Thor $(2002,2003)$. Briefly, groups of 5 females were placed in small respiration glass chambers $(400 \mu \mathrm{l})$ while a peristaltic pump maintained a steady

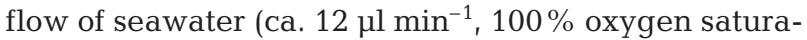
tion). The oxygen concentration of the outflow from the glass chambers was monitored continuously with polarographic oxygen electrodes connected through an amplifier to data acquisition hardware. The electrodes and the outflows from the glass chambers were connected with lengths of Tygon tubing never exceeding $5 \mathrm{~mm}$. Five experimental chambers (with copepods) and 1 or 2 reference chambers (without copepods) were monitored simultaneously. The reference chambers received the same inflow water as the experimental chambers so that differences due to either respiration or photosynthetic activity by algae or bacteria were minimized. Before the experiments, the system was completely flushed with water containing the appropriate salinity and food. At the given flow rate and chamber volume, equilibrium conditions in the chambers is reached in $100 \mathrm{~min}$. The copepods were placed in the chambers 1 to $2 \mathrm{~h}$ before the measurements, and during the experiments the chambers were kept in the dark to minimize disturbances. The output voltages of the amplified oxygen signals from each chamber were recorded every minute. Respiration rates $\left(r, \mathrm{nl} \mathrm{O}\right.$ ind. $^{-1}$ $\mathrm{min}^{-1}$ ) were calculated following Thor $(2002,2003)$ :

$$
r=\frac{S \times v}{U_{\mathrm{s}} \times n}\left(U_{\text {ref }}-U\right)
$$

where $S$ is the solubility of oxygen in $\mathrm{ml} \mathrm{O}_{2} \mathrm{l}^{-1}$ assuming $100 \%$ saturation of the inflow water, $v$ is the flow rate of water through the chambers in $\mathrm{ml} \mathrm{min}^{-1}$, and $n$ is the number of individuals in the chamber. $U_{\mathrm{s}}$ is the output voltage of the amplified oxygen electrode signal at saturation, $U_{\text {ref }}$ is the electrode signal from the reference chambers, and $U$ is the electrode signal from chambers containing copepods.

The oxygen pressure in the chambers was lowered 6.8 to $10.4 \%$ due to copepod respiration. This was sufficient to ensure reliable differences between copepod chambers and references without subjecting the copepods to unnaturally low oxygen levels.

Data analysis. Weight-specific rates were used to compare responses to experimental salinities for each species using 1-way ANOVA and a Fisher's least significant difference (LSD) post hoc test. Variables were tested for homoscedasticity (Levane's test) and transformed if necessary. Ratios (GGE = EPR/ingestion rate; Absorption Efficiency, AE = 1 -[egestion rate/ingestion rate], and $\mathrm{CG}=$ respiration rate/EPR) or percentages (EHS) were arcsine square-root transformed.

RNA data were log-transformed prior to statistical analysis and the effects of salinity were analyzed by 
1-way ANOVA with a Newman-Keuls multiple comparison test, which included the extension to allow for unequal sample sizes. Because 3 copepods from each experimental bottle were analyzed individually, the basic data unit was the bottle mean, and for each treatment a grand mean along with SE was calculated. In all cases, significance was considered when $\mathrm{p}<0.05$.

\section{RESULTS}

\section{Acartia tonsa}

Filtering and ingestion rates were not significantly affected by salinity $\left(F_{4,15}=2.9, \mathrm{p}=0.059\right.$, and $F_{4,15}=2.8$, $\mathrm{p}=0.067$, respectively; Fig. 1); Filtration rate $(\mathrm{F})$ showed a dome-shaped response to salinity with highest rates $\left(36 \mathrm{ml}\right.$ ind.$\left.^{-1} \mathrm{~d}^{-1}\right)$ at salinities of 10 and 20. EPR was also highest at 20 (27 eggs ind..$^{-1} \mathrm{~d}^{-1}$ ), with lower rates at high and low salinities $\left(F_{4,15}=11.2, \mathrm{p}<0.05\right.$; Fig. 2). PPR was highest at extreme salinities (2 and $33)$, and lowest at a salinity of $5\left(F_{4,12}=11.3, \mathrm{p}<0.05\right.$;
Fig. 2). The response of respiration rate $(r)$ was also dome-shaped with higher rates at 5 and $20\left(F_{4,19}=4.3\right.$, $\mathrm{p}<0.05$; Fig. 2); GGE was not significantly affected by salinity $\left(F_{4,15}=2.8, p=0.062\right.$, Fig. 3). Absorption efficiency (AE) was highest from salinities between 5 and 20 (range 54 to $64 \%$ ), intermediate at 33 and lowest $(40 \%)$ at $2\left(F_{4,12}=7.5, \mathrm{p}<0.05 ;\right.$ Fig. 3$)$. CG was highest over low salinities (2 to 10 , range 1.0 to 1.43 ), intermediate at 20 and minimum at $33(0.68)\left(F_{4,15}=9.0, \mathrm{p}<\right.$ 0.05 ; Fig. 3). RNA concentrations largely followed the responses of feeding and EPR. RNA levels did not differ between treatments except for individuals exposed to a salinity of 5 , which had significantly lower values $\left(F_{4,15}=3.8, \mathrm{p}<0.05\right.$, Fig. 4$)$. The overall effect of salinity on EHS was not significant $\left(F_{4,10}=3.3, \mathrm{p}=0.058\right.$, Fig. 5). Egg diameter increased with decreasing salinity $\left(F_{4,220}=289, \mathrm{p}<0.05\right.$, Fig. 5$)$, egg volume at a salinity of 2 being $51.3 \%$ larger compared to a salinity of 33 . RF also differed among treatments $\left(F_{4,10}=4.5, \mathrm{p}<0.05\right.$; Fig. 5), with maximum values (15 to 19 nauplii ind. ${ }^{-1}$ $\mathrm{d}^{-1}$ ) in a salinity range of 10 to 33 , and minimum values (11 nauplii ind..$^{-1} \mathrm{~d}^{-1}$ ) at a salinity of 2 .
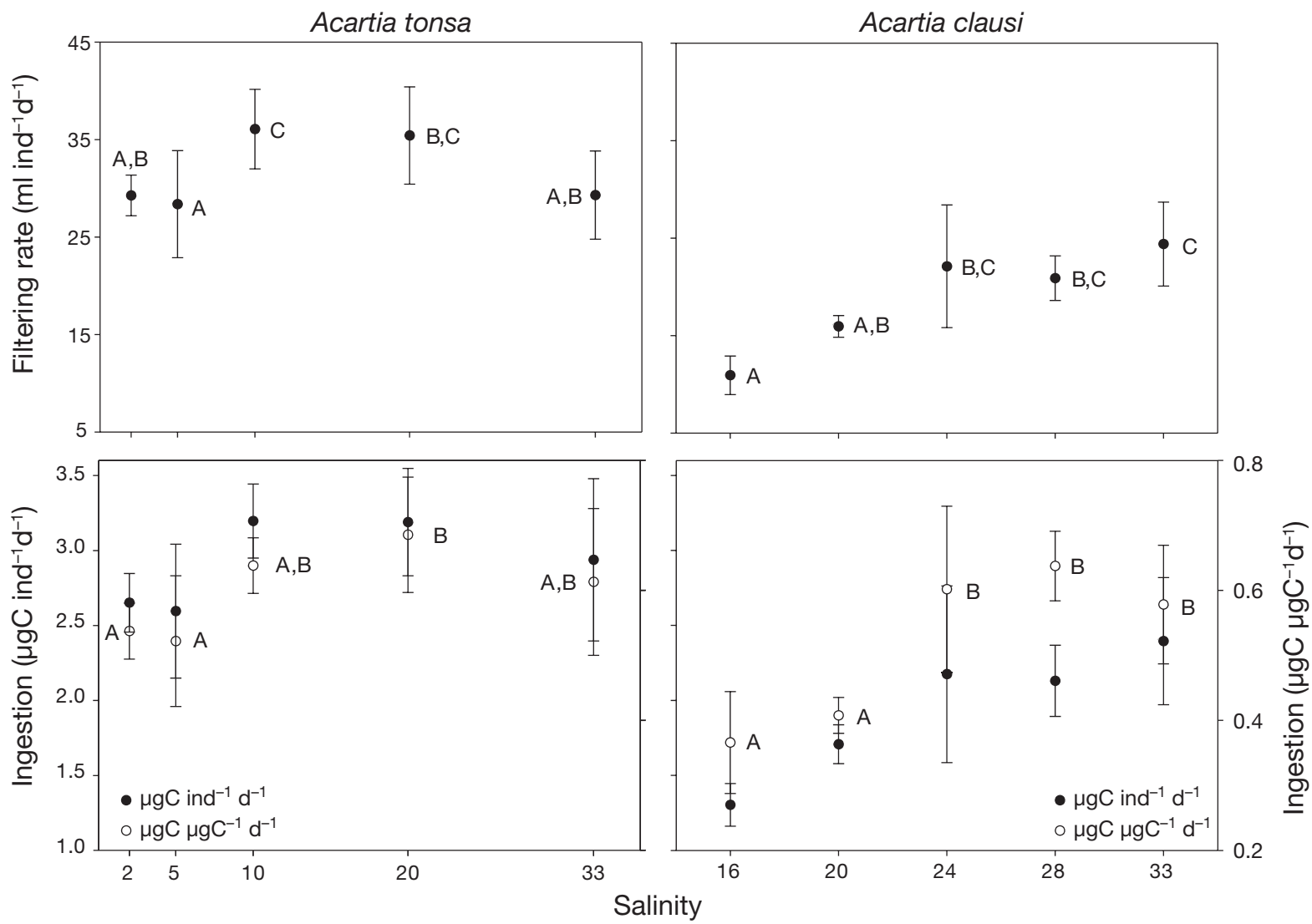

Fig. 1. Acartia tonsa and A. clausi. Per capita and weight-specific filtering rates and ingestion rates of individuals subject to different salinities. Points represent means $(n=4)$ and error bars indicate SDs. Letters correspond to statistically homogeneous groups (LSD post hoc test, $\mathrm{p}<0.05$ ) 

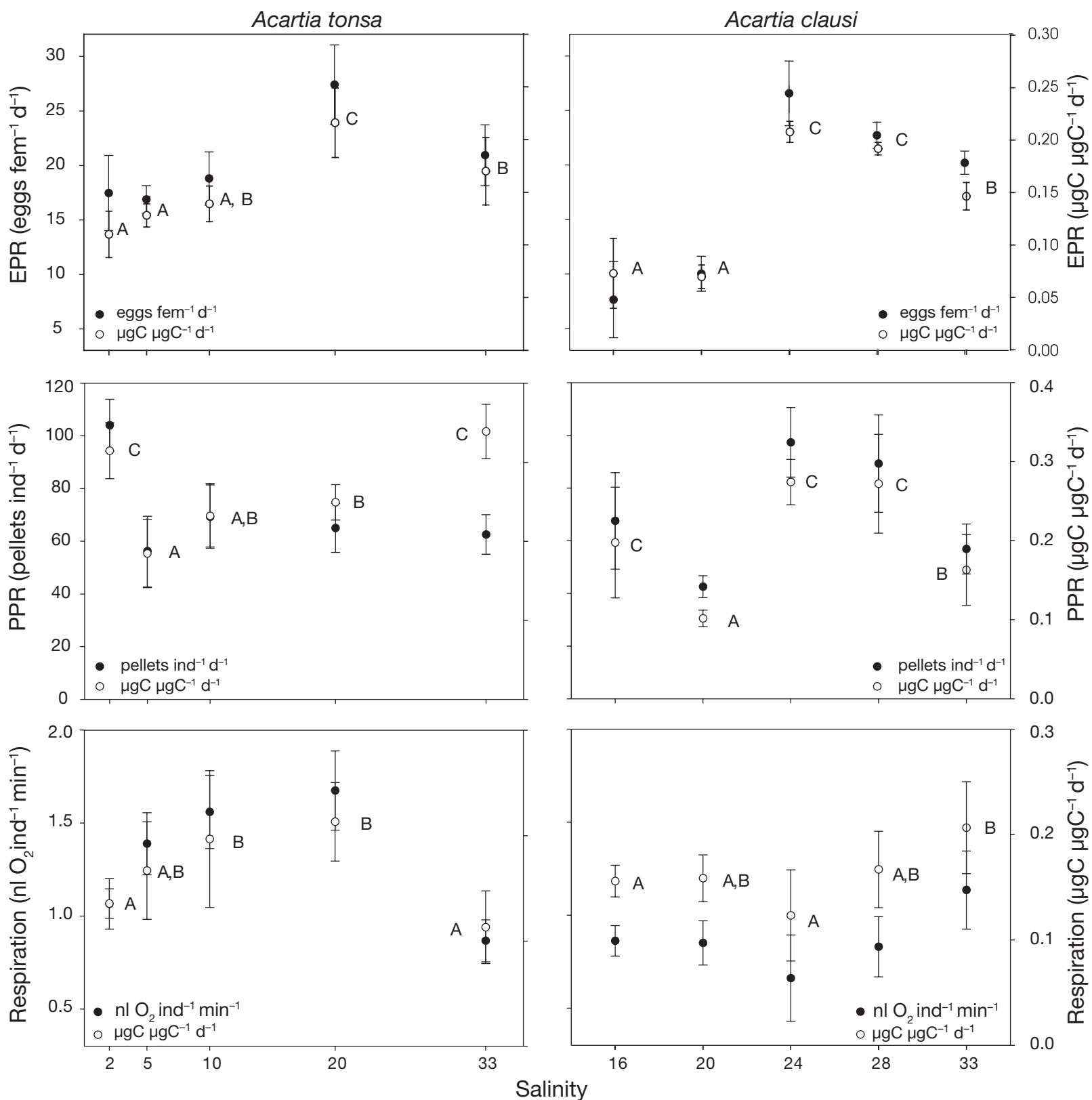

Fig. 2. Acartia tonsa and A. clausi. Per capita and weight-specific egg production (EPR), pellet production (PPR) and respiration rates of individuals subject to different salinities. Points represent means $(\mathrm{n}=4)$ and error bars indicate SDs (except for respiration data where $\mathrm{n}$ varies between 4 and 6). Letters correspond to statistically homogeneous groups (LSD post hoc test, $\mathrm{p}<0.05$ )

\section{Acartia clausi}

Filtering and ingestion rates increased significantly with salinity from ca. $11 \mathrm{ml}$ ind. ${ }^{-1} \mathrm{~d}^{-1}$ at a salinity of 16 to a maximum of $24 \mathrm{ml}$ ind..$^{-1} \mathrm{~d}^{-1}$ at a salinity of $33\left(F_{4,13}=7.4, \mathrm{p}<0.05\right.$; Fig. 1). Nevertheless, EPR was highest at intermediate salinities (maximum 27 eggs ind. ${ }^{-1} \mathrm{~d}^{-1}$ at a salinity of 28) and lower at high and low salinities (minimum 8 eggs ind. ${ }^{-1} \mathrm{~d}^{-1}$ at a salinity of 16$)\left(F_{4,13}=70.2, p<0.05\right.$; Fig. 2). Likewise,
PPR was highest at intermediate salinities (maximum 97 pellets ind. ${ }^{-1} \mathrm{~d}^{-1}$ at a salinity of 24$)$, and lower at high and low salinities $\left(F_{4,13}=22.7, \mathrm{p}<0.05\right.$; Fig. 2$)$. Respiration rates were lowest at intermediate salinity (0.66 $\mathrm{nl} \mathrm{O}_{2}$ ind.- $\mathrm{min}^{-1}$ at a salinity of 24$)$, and increased towards the extremes (maximum: $1.13 \mathrm{nl}$ $\mathrm{O}_{2}$ ind. $^{-1} \mathrm{~min}^{-1}$ at a salinity of 33) $\left(F_{4,17}=3.3, \mathrm{p}<0.05\right.$; Fig. 2). GGE was highest at salinities of 24 and 28 (maximum $36 \%$ ), intermediate at a salinity of 33 $(26 \%)$ and lowest at lower salinities $(17 \%)\left(F_{4,13}=\right.$ 

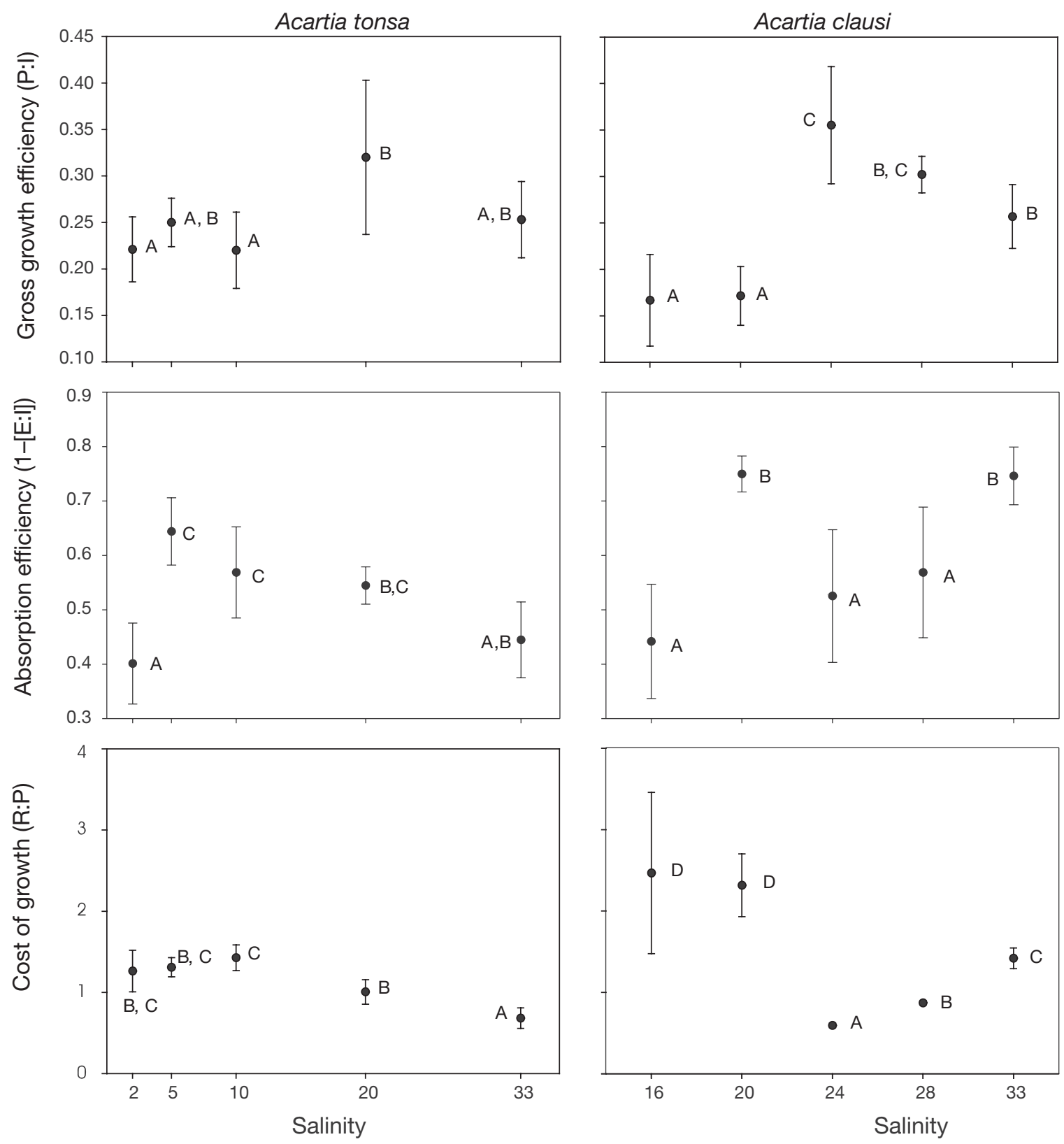

Fig. 3. Acartia tonsa and A. clausi. Gross growth efficiency, absorption efficiency and cost of growth of individuals subject to different salinities. Points represent means $(n=4)$ and error bars indicate SDs. Letters correspond to statistically homogeneous groups (LSD post hoc test, $\mathrm{p}<0.05$ )

12.5, p $<0.05$; Fig. 3). AE increased with salinity (maximum $75 \%$ ), with the exception of a salinity of 20 (Fig. 3). CG varied with salinity $\left(F_{4,12}=6.9, \mathrm{p}<\right.$ $0.05)$ and was inversely related to GGE with the minimum value (0.59) at a salinity of 24 , and increasing towards both ends of the salinity gradient (although CG at low salinities were higher by a factor of ca. 2 compared to CG at highest salinities; Fig. 3). Similar to Acartia tonsa, RNA dynamics mirrored that of feeding and egg production (Fig. 4). There was a significant tendency for RNA concentration to increase with increasing salinity (post test for linear trend, $\mathrm{p}<$ 0.02). RNA levels were significantly lower when copepods were exposed to 16 and 20 compared to $24\left(F_{4,14}=3.8, \mathrm{p}<0.05\right.$; Fig. 4$)$.

Egg size was significantly larger at a salinity of 16 $\left(F_{4,277}=21.5, \mathrm{p}<0.05\right.$; Fig. 5) with significantly lower EHS $(20 \%)$ compared to salinities of 20 to 33 (65 to $97 \%)\left(F_{4,10}=18.0, \mathrm{p}<0.05\right.$; Fig. 5$)$. RF was positively related to salinity $\left(F_{4,9}=20.1, \mathrm{p}<0.05\right)$, with 1.7 and ca. 20 nauplii ind. ${ }^{-1} \mathrm{~d}^{-1}$ at salinities of 16 and 33 , respectively. 


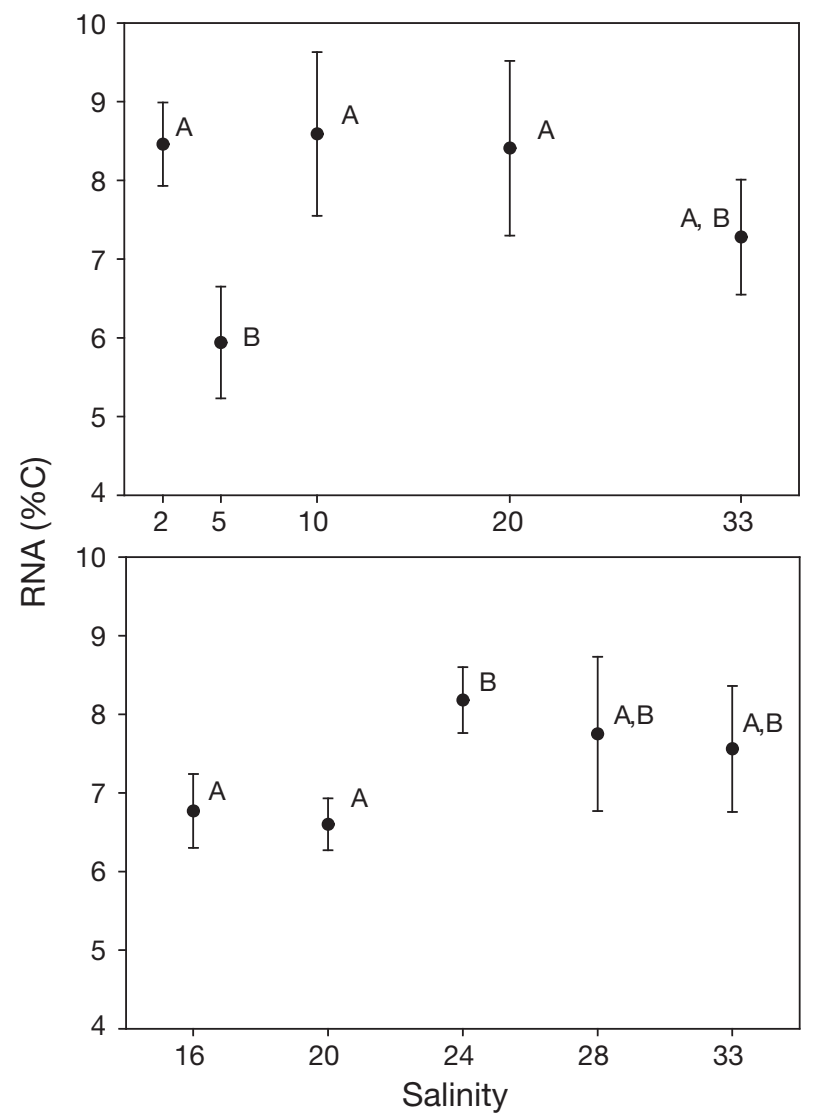

Fig. 4. Acartia tonsa and A. clausi. RNA concentration in single individuals subject to different salinity levels. Points represent means $(n=3)$ and error bars indicate SDs. Letters correspond to statistically homogeneous groups (TukeyKramer post hoc test, $\mathrm{p}<0.05$ )

\section{Energy budget}

Table 1 summarizes the energy budget for Acartia tonsa and A. clausi under different salinities. Theoretically, the balance represented by the difference between ingestion and the sum of production, respiration and egestion may be an indicator of non-equilibrium metabolism; however, in practice such difference also includes the overall error involved in the estimation of the components of the energy balance, and thus gives an indication of the magnitude of that error. The budget for $A$. tonsa showed a reasonable balance, and the difference ranged from 1 to $11 \%$ (average $=5.0 \%$ ). Egg production, respiration and egestion accounted for similar fractions of the budget at salinities of 10 and 20, while production and egestion decreased at lower salinities. The budget for A. clausi was less balanced, as shown by larger differences between carbon ingestion and allocation that ranged from 1 to $19 \%$ (average = $10.8 \%)$. Production was higher than respiration at intermediate salinities (24 and 28), and the opposite was true at both low (16 and 20) and high (33) salinities.

\section{DISCUSSION}

Environmental stress models predict that abiotic stress will differentially affect interacting species, thereby altering the outcome of species competition along environmental gradients (Menge \& Olson 1990) like those in coastal and estuarine regions. Understanding the physiological mechanisms that ultimately underlie patterns of community structure, and predicting how a species will interact with competitors or predators is essential for ecological and evolutionary studies. Assessment of an organismal response (i.e. physiological condition, metabolic rates) to environmental factors could be efficiently complemented with a variety of biomarkers to provide a deeper understanding of alterations in metabolic pathways that impact on performance, growth or reproductive output (Dahlhoff 2004). In particular, RNA-based indices have been related to both long- and short-term growth and nutritional conditions in a number of crustacean species (see Dahlhoff 2004 and references therein) including copepods (Saiz et al. 1998, Wagner et al. 2001, Gorokhova 2003). In our experiments, however, food availability was invariant between the treatments and therefore RNA concentrations reflected growth response of copepods to different salinities. To our knowledge, this is the first time that this biomarker has successfully been used for the diagnosis of stress response in copepods subject to suboptimal salinities.

\section{Salinity effects on Acartia tonsa energy partitioning}

Our results confirm the euryhaline character of Acartia tonsa suggested by field and experimental studies (Lance 1963, 1965, Cervetto et al. 1999; salinity range ca. 1 to 72). The rates of feeding, production and respiration showed consistent responses, i.e. highest rates over the intermediate salinity range (10 to 20 ) gradually decreasing at both lower and higher salinities (Figs. 1 \& 2). This consistency suggests that $A$. tonsa's salinity response could be explained by a primary response of maximum feeding in the salinity range of 10 to 20 , and concomitant responses of production and respiration. Higher production at intermediate salinities likely resulted from higher feeding, while respiration correlates to production through SDA and was consequently highest in the same range (Kiørboe et al. 1985, Thor 2003). Alternatively, lower affinity to oxygen due to altered haemolymph ionic composition may have induced decreased respiration at low salinities (Magnum 1981, Diefenbach \& Magnum 1983; sensu Brix et al. 1990).

The changes in filtering and ingestion rates between different salinities were consistent with the pattern earlier noted by Lance (1964) for Acartia spp. below 

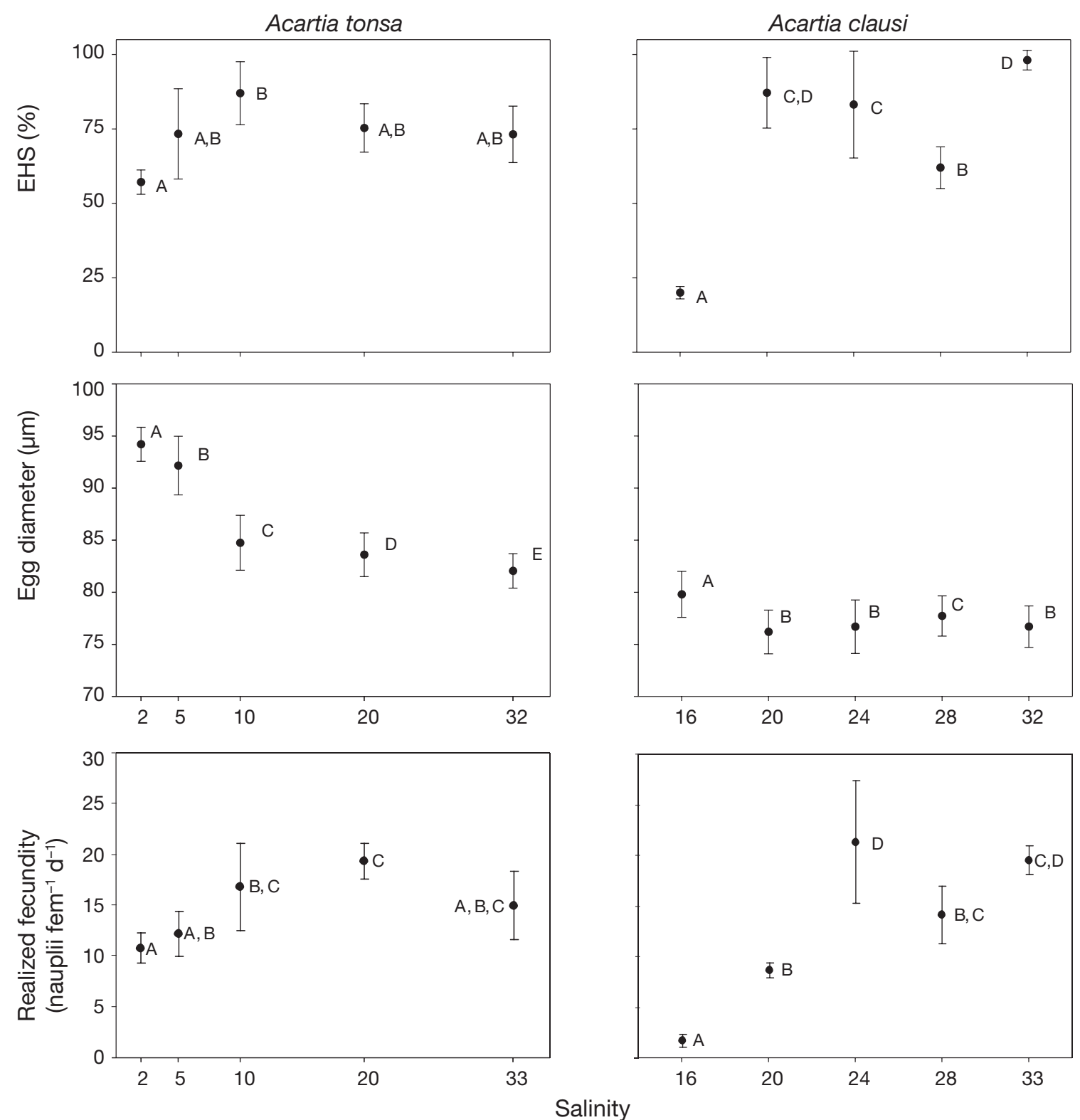

Fig. 5. Acartia tonsa and A. clausi. Egg hatching success (EHS), egg diameter and realized fecundity of individuals subject to different salinity levels. Points represent means $(\mathrm{n}=4)$ and error bars indicate SDs (except for egg diameter where $\mathrm{n}=50)$. Letters correspond to statistically homogeneous groups (LSD post hoc test, $\mathrm{p}<0.05$ ). The number of eggs in hatching experiments was between 175 and 291 (mean = 213) for $A$. tonsa, and between 58 and $284($ mean =184) for A. clausi

$60 \%$ full-strength sea water (a salinity of ca. 20). Similarly, respiration rates were consistent with early observations by Conover (1956) $\left(95 \mathrm{nl} \mathrm{O}_{2}\right.$ ind..$^{-1} \mathrm{~h}^{-1}$ at $20^{\circ} \mathrm{C}$ ), Anraku (1964a) (29 to $75 \mathrm{nl} \mathrm{O}$ ind. $^{-1} \mathrm{~h}^{-1}$ at $15^{\circ} \mathrm{C}$ and 67 to $92 \mathrm{nl} \mathrm{O}_{2}$ ind. ${ }^{-1} \mathrm{~h}^{-1}$ at $22^{\circ} \mathrm{C}$ ) and others (Kiørboe et al. 1985, Thor 2003), even though direct comparisons are hampered by differences in the feeding conditions during the experiments. Also, the response pattern of respiration and EPR matched earlier results over comparable salinity ranges (Lance 1965, for respiration rates; Castro-Longoria 2003, for EPR; Fig. 2).
Conversely, our results only partially agree with Gaudy et al. (2000) who found no differences in feeding at salinities of 15 to 35, but recorded significantly higher respiration rates at the highest salinity. However, these results are not easily comparable to ours since the respiration rates reported were ca. 1 order of magnitude higher than in the present study and other observed values for the same species (e.g. Kiørboe et al. 1985, Thor 2003, and references in previous paragraph, last sentence).

Our present results do not suggest a high energetic cost of osmoregulation at low salinities. Previous stud- 
Table 1. Acartia tonsa and A. clausi. Partitioning of ingested carbon into egg production, respiration and egestion under differ-

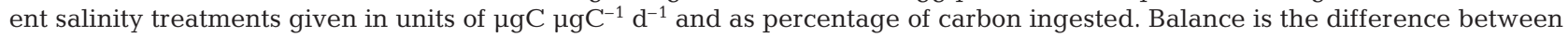
carbon gained by ingestion and lost to the allocated functions measured. Values in parentheses are SDs; $\mathrm{n}=4$ in all cases except for respiration measurements, where $\mathrm{n}=4$ to 6

\begin{tabular}{|c|c|c|c|c|c|c|}
\hline & Salinity & Ingestion & Production & Respiration & Egestion & Balance \\
\hline \multirow[t]{9}{*}{ Acartia tonsa } & 2 & $0.54(0.04)$ & $\begin{array}{c}0.12(0.02) \\
21 \%\end{array}$ & $\begin{array}{c}0.14(0.01) \\
25 \%\end{array}$ & $\begin{array}{c}0.31(0.04) \\
59 \%\end{array}$ & $\begin{array}{c}-0.023 \\
4 \%\end{array}$ \\
\hline & 5 & $0.52(0.10)$ & $0.13(0.01)$ & $0.17(0.05)$ & $0.18(0.04)$ & 0.043 \\
\hline & & & $25 \%$ & $32 \%$ & $35 \%$ & $8 \%$ \\
\hline & 10 & $0.64(0.04)$ & $0.15(0.02)$ & $0.20(0.06)$ & $0.23(0.04)$ & 0.070 \\
\hline & & & $22 \%$ & $31 \%$ & $36 \%$ & $11 \%$ \\
\hline & 20 & $0.69(0.09)$ & $0.23(0.04)$ & $0.21(0.04)$ & $0.25(0.02)$ & 0.008 \\
\hline & & & $31 \%$ & $31 \%$ & $36 \%$ & $1 \%$ \\
\hline & 33 & $0.61(0.11)$ & $0.18(0.03)$ & $0.11(0.03)$ & $0.34(0.03)$ & -0.009 \\
\hline & & & $28 \%$ & $18 \%$ & $55 \%$ & $1 \%$ \\
\hline \multirow[t]{10}{*}{ Acartia clausi } & 16 & $0.37(0.08)$ & $0.07(0.03)$ & $0.16(0.02)$ & $0.20(0.061)$ & -0.067 \\
\hline & & & $20 \%$ & $43 \%$ & $56 \%$ & $18 \%$ \\
\hline & 20 & $0.41(0.03)$ & $0.07(0.01)$ & $0.16(0.02)$ & $0.10(0.010)$ & 0.078 \\
\hline & & & $17 \%$ & $39 \%$ & $25 \%$ & $19 \%$ \\
\hline & 24 & $0.60(0.13)$ & $0.21(0.01)$ & $0.12(0.04)$ & $0.27(0.029)$ & -0.004 \\
\hline & & & $35 \%$ & $20 \%$ & $46 \%$ & $1 \%$ \\
\hline & 28 & $0.64(0.05)$ & $0.19(0.01)$ & $0.17(0.04)$ & $0.27(0.063)$ & 0.007 \\
\hline & & & $30 \%$ & $26 \%$ & $43 \%$ & $1 \%$ \\
\hline & 33 & $0.58(0.09)$ & $0.15(0.02)$ & $0.21(0.04)$ & $0.14(0.030)$ & 0.088 \\
\hline & & & $25 \%$ & $36 \%$ & $24 \%$ & $15 \%$ \\
\hline
\end{tabular}

ies have suggested that Acartia tonsa could only weakly (if at all) regulate extracellular water balance at salinities below 31, but the evidence is inconclusive (Lance 1965). In our experiments, respiration did not increase with decreasing salinity, revealing that osmoregulation represented, at most, only a small fraction of the energy budget, as has been observed for other crustaceans (0.4 and $1.3 \%$ in Astacus and Eriochir, respectively; Potts 1954, Schmidt-Nielsen 1991), and for the copepod Eurytemora affinis (Roddie et al. 1984).

\section{Salinity effects on Acartia clausi energy partitioning}

In contrast to Acartia tonsa, A. clausi had low tolerance to diluted seawater in the salinity range of 16 to 20 . This result was unexpected considering the reported salinity tolerance for A. clausi in the salinity range of 2 to 65 (Cervetto et al. 1995), and suggests potential differences in the responses to salinity among populations.

The metabolic response of Acartia clausi was complex and likely reflected the effects of osmotic stress at low salinities (Figs. 1 to 3), although the exact mechanism of this stress is still unclear. Feeding was enhanced at high and medium salinities, decreasing as salinities decreased. The EPR was highest at a salinity of 24 and lowest at salinities of 16 and 20, thus partially co-varying with feeding rate, whereas respiration showed the exact opposite trend. Therefore, at salinities <24, SDA-related variability (i.e. close coupling between ingestion, pro- duction and respiration) cannot explain the observed pattern, as found for A. tonsa. Rather, it seems that the variations in EPR were caused by variations in CG, which increased more than 2 -fold at low salinities. Thus, for $A$. clausi there were detrimental effects on total metabolism (i.e. osmotic stress response) at low salinities (16 to 20) but also to some extent at the highest salinities, suggesting a physiological optimum close to 24 . This caused reduced EPR with very low GGE as a result.

Acartia clausi is an osmoconformer in the salinity range of 24 to 32 (Bayly 1972), but osmoregulation and metabolic responses to salinity are less well known compared to A. tonsa. Gaudy et al. (2000) did not find any differences in the ingestion of $A$. clausi subjected to salinities $<15$ and $>30$, respectively. However, their results are not directly comparable to ours since they used animals with a different salinity tolerance (Cervetto et al. 1995) compared to those used in the present study. The feeding response of $A$. clausi observed here is comparable to other copepods like Calanus helgolandicus, A. bifilosa and A. discaudata which also responded with lower feeding rates at reduced salinities (Lance 1965). Also, the observed pattern of EPR in relation to salinity was consistent with previous results for A. clausi at salinities of 15 and 35 (Castro-Longoria 2003).

Respiration rates of Acartia clausi were consistent with those obtained earlier $\left(20^{\circ} \mathrm{C}\right.$ : $50 \mathrm{nl} \mathrm{O}$ ind. $^{-1} \mathrm{~h}^{-1}$, Conover $1956 ; 5^{\circ} \mathrm{C}$ : 13 to $67 \mathrm{nl} \mathrm{O}_{2}$ ind.$^{-1} \mathrm{~h}^{-1}$; and $22^{\circ} \mathrm{C}$ : 33 to $67 \mathrm{nl} \mathrm{O}_{2}$ ind..$^{-1} \mathrm{~h}^{-1}$; Anraku 1964a). Depressed res- 
piration of A. clausi at low salinities was likely the consequence of osmotic stress, as has been observed for crab larvae (Anger et al. 1998), and copepods (Anraku 1964a). For A. clausi, Gaudy et al. (2000) found no significant differences in respiration rates between salinities of 15, 25 and 35, but a tendency to decreased respiration at diluted salinities.

Intracellular free amino acids are important osmolytes in osmoconforming marine invertebrates: as the salinity in the water rises or falls, the concentration of amino acids in the cells increase or decrease so that they remain isotonic with the surroundings. It has been suggested that a decrease in amino acid concentration could be achieved by the synthesis of proteins (Pierce 1982). Moreover, synthesis of stress proteins could be induced by osmotic stress in a variety of organisms (Tirad et al. 1997), including copepods (Gonzalez \& Bradley 1994). The proteins induced may be involved in cellular transport machinery regulating solute efflux and influx or serve as chaperones protecting vital proteins from denaturing (Gonzalez \& Bradley 1994, Sinha \& Häder 1996). However, RNA levels in Acartia clausi did not indicate enhanced protein synthetic activity at low salinities. This can probably be explained by the relatively long incubation period at experimental salinities (24 h acclimation plus experiment); by the end of the experiments, the synthesis of stress proteins was over, and elevated RNA levels were no longer required. In Eurytemora affinis, osmotic shock protein synthesis was observed $5 \mathrm{~h}$ after osmotic shock (Gonzalez \& Bradley 1994). In line with this, A. clausi showed clearly elevated RNA levels after a $1 \mathrm{~h}$ exposure to a salinity of 20 in shortterm salinity shock experiments (authors' unpubl. data). This interpretation implies that synthesis of salinity stress proteins constitutes a short-term response to salinity change and declines in long-term exposure to sub-optimal salinities. Therefore, to examine the acute osmotic response at the level of gene transcription, one would use animals exposed to osmotic stress without prior acclimation. In this way, RNA contents could be useful indicators of salinity stress on short timescales.

\section{Egg hatching success and realized fecundity}

In both species, EHS was lowest at the lowest salinity tested, but the effect was most pronounced in Acartia clausi (Fig. 5). Variable egg size between different salinities indicates that the eggshell is permeable to water and thus embryos in the different treatments were actually experiencing different osmotic pressures. Moreover, higher embryonic mortality at low salinities for A. clausi suggests that embryos are more sensitive than adults to decreasing salinity. Such narrow environmental tolerance during early life stages is a common pattern in copepods (Tester \& Turner 1991, Chinnery \& Williams 2004, Devreker et al. 2004). Castro-Longoria (2003) found consistently decreasing EHS in A. clausi from ca. 90 to $0 \%$ at salinities of 35 and 15 , respectively. Our EHS data followed the same trend, although values were slightly higher and more variable. Similar to our results, Castro-Longoria (2003) did not find a pattern in the salinity range of 15 to 35 for A. tonsa. In contrast, Chinnery \& Williams (2004) found lower EHS (ca. 56\%) for A. tonsa at salinities of 15.5 and 20.6 compared to salinities of 25.1 and 33.3. Furthermore, they did not find a clear pattern over the same range for $A$. clausi.

The variability in RF among treatments indicates the effects of salinity on the fitness of these 2 species. For Acartia tonsa, there appeared to be a broad salinity optimum extending from 10 to 33 (RF: ca. 15 to 19 nauplii ind. ${ }^{-1} \mathrm{~d}^{-1}$ ). However, even in heavily diluted seawater (salinities of 5 and 2), there was a substantial production of nauplii (12.1 and 10.7 nauplii ind. ${ }^{-1} \mathrm{~d}^{-1}$, respectively). For $A$. clausi, optimal conditions were a salinity of 24 and higher (ca. 14 to 21 nauplii ind. ${ }^{-1} \mathrm{~d}^{-1}$ ), but at the lower salinities RF sharply decreased to values that are most likely below the population existence limit (1.7 nauplii ind..$^{-1} \mathrm{~d}^{-1}$ ).

How do our results contribute to understanding distribution patterns of Acartia tonsa and A. clausi? In nature, other variables besides salinity affect abundance and distribution of copepods, notably temperature, food availability and predation. Early reports show that in ecosystems where both $A$. clausi and A. tonsa occur, they are generally not found simultaneously but tend to replace each other seasonally (Conover 1956, Jeffries 1962, Anraku 1964b, Lawrence et al. 2004). In environments with small salinity fluctuations (i.e. Long Island Sound, Buzzards Bay), temperature seems to be responsible for the temporal succession. A. clausi prefers colder waters than A. tonsa (Gonzalez 1974); consequently, A. clausi dominates during winter months and is replaced by A. tonsa in warmer periods (Conover 1956, Anraku 1964b). However, along wider salinity gradients (e.g. in estuaries) A. tonsa usually dominates the low salinity upper reaches, usually more eutrophic, whereas A. clausi is found at medium and high salinities, closer to the sea; that trend may add to the seasonal signal (Jeffries 1962, Castro-Longoria 2003, Lawrence et. al 2004). A. tonsa is evolutionarily adapted to highenergy expenditure: it respires more (Conover 1956, Anraku 1964a), has higher fecundity (for references, see Mauchline 1998), and is less efficient at converting ingested food into biomass than A. clausi, but also eats more (Tiselius et al. 1997). This is consistent with theo- 
ries of A. tonsa being restricted to areas of high food availability (Paffenhöfer \& Stearns 1988). Feeding for a higher fraction of time is often related to higher predation risk: feeding individuals are more vulnerable to visual and rheotactic predators due to higher encounter rates and enhanced emission of hydrodynamic signals (Yen 1987, Tiselius et al. 1997), and a more conspicuous body (colored gut) (Tsuda et al. 1998). In fact, A. tonsa displays a higher jumping frequency (food searching behavior), feeds for a larger fraction of the time, and consequently is likely to suffer higher predation mortality compared to A. clausi (Tiselius et al. 1997). Dominance by $A$. tonsa is therefore most likely under conditions of high food and low salinity. Such conditions are typical in oligo- and mesohaline regions of many estuaries (i.e. usually salinities of 2 to 15), where $A$. tonsa can sustain the high-energy requirements and where competition with true marine copepods is reduced. At salinities $>20$, metabolic and reproductive performance of $A$. tonsa and $A$. clausi are similar, and a higher predation pressure on $A$. tonsa favors dominance by $A$. clausi, which is often the observed pattern. Strong dominance by $A$. tonsa at salinities $<10$ concurrent with peak abundances at salinities $>20$ (Waquoit Bay, Lawrence et al. 2004) support the idea that dominance at low salinities results from decreased competition, even if optimum salinity levels for A. tonsa are close to 20 (Lance 1965, Tester \& Turner 1991, Cervetto et al. 1999, the present study).

\section{Pre-adaptation salinity}

Experimental animals were obtained from laboratory cultures raised for several generations at a salinity of 33. It could be questioned whether the conditions in the cultures have pre-conditioned the copepods to high salinities, affecting the observed responses to this experimental factor; we believe that this would not compromise our results. If significant pre-conditioning had occurred, one would expect it to be most evident for a species naturally inhabiting lower salinities, i.e. Acartia tonsa. However, A. tonsa was the species that showed the widest tolerance to salinity and most consistent physiological responses over the whole salinity range tested, suggesting that the culture conditions did not significantly alter $A$. tonsa's natural, adaptive capacity acquired during the evolution of the species.

In conclusion, several processes contribute to the outcome of the interactions between Acartia tonsa and A. clausi along environmental gradients. Our results show that differential modulating effects of salinity on the energy budget and reproductive success of these 2 species may be important factors allowing them to exploit complementary niches. Basic physiological properties should be explicitly considered to predict the distribution and production of these copepods in nature.

Acknowledgements. This study was financially supported by the Swedish Royal Academy of Science (Arctic Paper fellowship to D.C.), the Swedish Research Council for Environment, Agricultural Sciences and Spatial Planning, the Swedish Environmental Protection Agency (Formas, SEPA; research grants to E.G.), and Wåhlströms Foundation (research grant to P.T.). C.M.A. acknowledges Göteborg University Marine Research Centre for kind support during work at Kristineberg Marine Research Station. We thank M. Appelgren (Marine Algal Culture Centre, Göteborg University) for providing algal strains, L. Rodríguez for copepod cultures, and G. Cervetto, L. Giménez, H. Dam and 4 anonymous reviewers for valuable comments on earlier versions of the manuscript.

\section{LITERATURE CITED}

Anger K, Spivak E, Luppi T (1998) Effects of reduced salinities on development and bioenergetics of early larval shore crab, Carcinus maenas. J Exp Mar Biol Ecol 220: 287-304

Anraku M (1964a) Influence of the Cape Cod Canal on the hydrography and on the copepods in Buzzards Bay and Cape Cod Bay, Massachusetts. II. Respiration and feeding. Limnol Oceanogr 9:195-206

Anraku M (1964b) Influence of the Cape Cod Canal on the hydrography and on the copepods in Buzzards Bay and Cape Cod Bay, Massachusetts. I. Hydrography and distribution of copepods. Limnol Oceanogr 9:46-60

Bayly IAE (1972) Salinity tolerance and osmotic behavior of animals in athalassic saline and marine hypersaline waters. Annu Rev Ecol Syst 3:233-268

Berggreen U, Hansen B, Kiørboe T (1988) Food size spectra, ingestion and growth of the copepod Acartia tonsa during development: implications for determination of copepod production. Mar Biol 99:341-352

Brand GW, Bayly IAE (1971) A comparative study of osmotic regulation in four species of calanoid copepod. Comp Biochem Physiol B 38:361-371

Brix O, Condó SG, Colosimo A, Giardina B (1990) The influence of salinity acclimation on the temperature sensitivity of oxygen binding to the haemocyanin of the prosobranch Neptunea antiqua. J Exp Biol 149:417-424

Castro-Longoria E (2003) Egg production and hatching success of four Acartia species under different temperature and salinity regimes. J Crustac Biol 23:289-299

Cervetto G, Pagano M, Gaudy R (1995) Adaptation aux variations de la salinité chez le copépode Acartia clausi. J Rech Océanogr 20:42-49

Cervetto G, Gaudy R, Pagano M (1999) Influence of salinity on the distribution of Acartia tonsa (Copepoda, Calanoida). J Exp Mar Biol Ecol 239:33-45

Chinnery FE, Williams JA (2004) The influence of temperature and salinity on Acartia (Copepoda: Calanoida) nauplii survival. Mar Biol 145:733-738

Conover SM (1956) Oceanography of Long Island Sound, 1952-1954. VI. Biology of Acartia clausi and A. tonsa. Bull Bingham Oceanogr Coll 15:156-233

Dahlhoff EP (2004) Biochemical indicators of stress and metabolism: applications for marine ecological studies. Annu Rev Physiol 66:183-207 
Devreker D, Souissi S, Seuront L (2004) Development and mortality of the first naupliar stages of Eurytemora affinis (Copepoda, Calanoida) under different conditions of salinity and temperature. J Exp Mar Biol Ecol 303:31-46

Diefenbach CO, Magnum CP (1983) The effects of inorganic ions and acclimation salinity on oxygen binding of the hemocyanin of the horseshoe crab Limulus polyphemus. Mol Physiol 4:197-206

Dutz J (1998) Repression of fecundity in the neritic copepod Acartia clausi exposed to the toxic dinoflagellate Alexandrium lusitanicum: relation between feeding and egg production. Mar Ecol Prog Ser 175:97-107

Farmer L (1980) Evidence for hyporegulation in the calanoid copepod Acartia tonsa. Comp Biochem Physiol A 65: 359-362

Frost BW (1972) Effect of size and concentration of food particles on the feeding behavior of the marine planktonic copepod Calanus pacificus. Limnol Oceanogr 17:805-815

Gaudy R, Cervetto G, Pagano M (2000) Comparison of the metabolism of Acartia clausi and A. tonsa: influence of temperature and salinity. J Exp Mar Biol Ecol 247:51-65

Gonzalez CRM, Bradley BP (1994) Salinity stress proteins in Eurytemora affinis. Hydrobiol 292/293:461-468

Gonzalez JG (1974) Critical thermal maxima and upper lethal temperatures for the calanoid copepods Acartia tonsa and A. clausi. Mar Biol 27:219-223

Gorokhova E (2003) Relationship between nucleic acid levels and egg production rates in Acartia bifilosa: implications for growth assessment of copepod in situ. Mar Ecol Prog Ser 262:163-172

Gorokhova E, Kyle M (2002) Analysis of nucleic acids in Daphnia: development of methods and ontogenetic variations in RNA-DNA content. J Plankton Res 24:511-522

Jeffries HP (1962) Copepod indicator species in estuaries. Ecology 43:730-733

Jónasdóttir SH, Kiørboe T, Tang KW, St. John M, Visser AW, Saiz E, Dam HG (1998) Role of diatoms in copepod production: good, harmless or toxic? Mar Ecol Prog Ser 172:305-308

Kiørboe T, Møhlenberg F, Hamburger K (1985) Bioenergetics of the planktonic copepod Acartia tonsa: relation between feeding, egg production and respiration, and composition of specific dynamic action. Mar Ecol Prog Ser 26:85-97

Lance J (1963) The salinity tolerance of some estuarine planktonic copepods. Limnol Oceanogr 8:440-449

Lance J (1964) Feeding of zooplankton in diluted sea-water. Nature 201:100-101

Lance J (1965) Respiration and osmotic behavior of the copepod Acartia tonsa in diluted sea water. Comp Biochem Physiol 14:155-165.

Lawrence D, Valiela I, Tomasky G (2004) Estuarine calanoid copepod abundance in relation to season, salinity, and land-derived nitrogen loading, Waquoit Bay, MA. Estuar Coast Shelf Sci 61:547-557

Magnum CP (1981) The influence of inorganic ions and $\mathrm{pH}$ on $\mathrm{HcOz}$ transport systems. In: Lamy J, Lamy J (eds) Invertebrate oxygen-binding proteins. Structure, Active Site, and Function. Marcel Dekker, New York, p 811-822

Mauchline J (1998) The biology of calanoid copepods. Adv Mar Biol 33:1-701

Menge BA, Olson AM (1990) Role of scale and environmental factors in regulation of community structure. Trends Ecol Evol 5:52-57

Mullin MM, Sloan PR, Eppley RW (1966) Relationship between carbon content, cell volume and area in marine phytoplankton. Limnol Oceanogr 11:307-311
Paffenhöfer GA, Stearns DE (1988) Why is Acartia tonsa (Copepoda; Calanoida) restricted to nearshore environments? Mar Ecol Prog Ser 42:33-38

Pierce SK (1982) Invertebrate cell volume control mechanisms: a coordinated use of intracellular amino acids and inorganic ions as osmotic solute. Biol Bull 163:405-416

Potts WTW (1954) The energetics of osmotic regulation in brackish and freshwater animals. J Exp Biol 31:618-630

Roddie BD, Leakey RJG, Berry AJ (1984) Salinity-temperature tolerance and osmoregulation in Eurytemora affinis (Poppe) (Copepoda: Calanoida) in relation to its distribution in the zooplankton of the upper reaches of the Forth estuary. J Exp Mar Biol Ecol 79:191-211

Saiz E, Calbet A, Fara A, Berdalet E (1998) RNA content of copepods as a tool for determining adult growth rates in the field. Limnol Oceanogr 43(3):465-470

Schmidt-Nielsen K (1991) Animal physiology: adaptation and environment, 4th edn. Cambridge University Press, Cambridge

Sinha RP, Häder DP (1996) Response of a rice field cyanobacterium Anabena sp. to physiological stressors. Environ Exp Bot 36:147-155

Soetaert K, Herman PMJ (1994) One foot in the grave: zooplankton drift into the Westerschelde estuary (The Netherlands). Mar Ecol Prog Ser 105:19-29

Tester PA, Turner JT (1991) Why is A. tonsa restricted to estuarine habitats? Bull Plankton Soc Jpn (spec vol):603-611

Thor P (2002) Specific dynamic action and carbon incorporation in Calanus finmarchicus copepodites and females. J Exp Mar Biol Ecol 272:159-169

Thor P (2003) Elevated respiration rates of the neritic copepod Acartia tonsa during recovery from starvation. J Exp Mar Biol Ecol 283:133-143

Tirad CT, Grossfeld RM, Levine JF, Kennedy-Stoskopf S (1997) Effect of osmotic shock on protein synthesis of Oyster hemocytes in vitro. Comp Biochem Physiol A 116:43-49

Tiselius P, Jonsson PR, Kaartvedt S, Olsen EM, Jørstad T (1997) Effects of copepod foraging behavior on predation risk: an experimental study of the predatory copepod Pareuchaeta norvegica feeding on Acartia clausi and A. tonsa (Copepoda). Limnol Oceanogr 42:164-170

Tsuda A, Saito H, Hirose T (1998) Effect of gut content on the vulnerability of copepods to visual predation. Limnol Oceanogr 43:1944-1947

Urban-Rich J, Hansell DA, Roman MR (1998) Analysis of copepod fecal pellet carbon using a high temperature combustion method. Mar Ecol Prog Ser 171:199-208

Uye S (1981) Fecundity studies of neritic clanoid copepods Acartia clausi Giesbrecht and A. steueri Smirnov: a simple empirical model of daily egg production. J Exp Mar Biol Ecol 50:255-271

Uye S (1982) Length-weight relationships of important zooplankton from the Inland Sea of Japan. J Ocean Soc Jpn 38:149-158

Wagner MM, Campbell RG, Boudreau CA, Durbin EG (2001) Nucleic acids and growth of Calanus finmarchicus in the laboratory under different food and temperature conditions. Mar Ecol Prog Ser 221:185-197

Wang WN, Wang AL, Bao L, Wang JP, Liu Y, Sun RY (2004) Changes of protein-bound and free amino acids in the muscle of the freshwater prawn Macrobrachium nipponense in different salinities. Aquaculture 233:561-571

Yen J (1987) Predation of Euchaeta norvegica Boeck on eggs and larvae of the Atlantic cod Gadus morhua L. J Exp Mar Biol Ecol 112:283-296

Submitted: August 10, 2005; Accepted: October 25, 2005

Proofs received from author(s): March 20, 2006 